\title{
EUROPEAN INTEGRATION CRIMINAL LAW POLICY AND ACHIEVEMENT OF FREEDOM AND SECURITY
}

\section{Liliya Timofeyeva}

Introduction. One of the main tasks of Criminal Law is to ensure the human security and freedom. Some issues related to security and freedom in Criminal Law were research by foreign and domestic scientists, including: P.A. Albrecht, V.K. Grischuk, M.W. Karchevskiy, N. Christie, N.A. Orlovska, A. Prince, N.A. Savinova, V.O. Tulyakov, S.O. Filippov, V.V. Shablystiy and others. However, in the context of European integration, as well as taking into account the changes in the reality of the perception of this task and the Criminal Law itself, it is different among scientists and scholars, as well as subjects of Criminal Law relations. Due to differences in perception, the effectiveness of Criminal Law is reduced. Contradictions between the attainment of individual liberty and the security of the state, in particular, can be traced to issues related to migration processes, transborder crimes, etc.

\section{Approaching European humanistic values}

The implementation of the Association Agreement between Ukraine, on the one hand, and the European Union, the European Atomic Energy Community and their Member States, has led to a set of significant regulatory and institutional changes in Ukraine.

European integration trends are embodied both in general terms and in individual Criminal Law institutions.

The Criminal Law of Ukraine should take into account the peculiarities of the impact of global and regional imbalances and conflicts on the rule of law, as well as the urgent need to protect people's security on the European continent.

The EU Treaty uses two terms: approximation and harmonization. The approximation implies achieving a certain level of conformity of the national legal system with the EU legal system; instead, harmonization is the main means of legal integration, approximation of the legal systems of the EU Member States. Harmonization of Ukrainian and EU 
legislation provides for harmonization of national legal norms with European norms, standards and principles ${ }^{1}$.

The state reserves the choice to implement international or European standards in national legislation or not. It is another matter that the implementation of certain provisions is a condition for accession to the EU. It should be noted that Ukraine has already taken some steps towards such an approximation, but there remain many unresolved issues, including methodological ones.

First of all, it is necessary to get closer to European values and principles.

It is very important that the Association Agreement emphasizes that Ukraine and the European Union share common values, including: respect for democratic principles, the rule of law, good governance, human rights and fundamental freedoms, including the rights of persons belonging to national minorities, non-discrimination against persons belonging to minorities, and respect for diversity, human dignity and commitment to the principles of a free market economy.

All of these values are humanistic and fit the model of the humanistic paradigm $^{2}$.

The values are also reflected in other Council of Europe, EU and international instruments, the Convention for the Protection of Human Rights and Fundamental Freedoms, ECtHR decisions and the like. It (values) are really common and not only for the EU and Ukraine, but also for many countries of the world, because they are human. Another thing is that it is not always an effective mechanism for their implementation.

Respect for democratic principles, human rights and fundamental freedoms, as defined in particular in the Helsinki Final Act of the 1975 Security and Cooperation Council in Europe and the Paris Charter for a New Europe of 1990, as well as in other relevant human rights instruments, among them the UN Universal Declaration of Human

${ }^{1}$ Trykhlib, K.O. (2014). Harmonizatsiia zakonodavstva Ukrainy i zakonodavstva YeS: nablyzhennia zahalnopravovoi terminolohii [Harmonization of Ukrainian and EU legislation: approximation of common law terminology]. Extended abstract of candidate's thesis. Kharkiv: NLU. Y. the Wise. P. 8-9. [in Ukrainian].

${ }^{2}$ Timofeyeva, L.Yu. (2019). Euro-integration and Criminal Law policy. Proceedings of the Int. sci. conf.: ECHR's Jurisprudence in Digital Era. (Pp. 93-93). Odesa: Publishing house "Helvetica. [in English]; Timofeyeva, L.Yu. (2018). Humanistychna paradyhma kryminal'noho prava Ukrayiny. [Humanistic paradigm of Criminal Law of Ukraine]. Extended abstract of candidate's thesis. Odesa: NU OLA. [in Ukrainian]. 
Rights 1948 and the Council of Europe Convention on the Protection of Human Rights and Fundamental Freedoms of 1950, as well as respect for the rule of law, must form the basis of the Parties' domestic and foreign policies and are fundamental to the cries of the Agreement. Ensuring respect for the principles of sovereignty and territorial integrity, inviolability of borders and independence, as well as counteracting the proliferation of weapons of mass destruction, related materials and their means of delivery, are also essential elements of the Agreement (Article 2 of the Association Agreement).

The rule of law, good governance, the fight against corruption, the fight against various forms of transnational organized crime and terrorism, the promotion of sustainable development and effective multilateralism are the main principles for strengthening relations between the Parties (Article 3).

The main components of the rule of law as one of the European principles are legality, legal certainty, and the prohibition of arbitrariness, access to independent and impartial justice, respect for human rights, non-discrimination and equality.

\section{Euro integration humanistic directions and providing freedom and security}

The Association Agreement sets out a number of important areas that have a humanistic content, directly related to criminal policy, and which Ukraine seeks to implement and approximate to EU law. Among them are: combating illegal migration and trafficking in human beings, organized crime, terrorism, environmental protection, strengthening interpersonal contacts ${ }^{3}$. These areas are highlighted in vain because they

\footnotetext{
${ }^{3}$ The Treaty of Lisbon under Art. 83.1 states that «The European Parliament and the Council may, by means of directives adopted in accordance with the ordinary legislative procedure, lay down minimum rules governing the definition of criminal offenses and sanctions for particularly serious offenses with a cross-border dimension, the nature or impact of such offenses or of special necessity to counter them on a common basis. These areas of crime are: terrorism, trafficking in human beings and sexual exploitation of women and children, drug trafficking, drug trafficking, money laundering, corruption, counterfeiting, cybercrime and organized crime. «The Stockholm Program wides» extends these ideas to the harmonization of EU criminal law disciplinary practice. / Tuliakov, V.O. (2018). «Eurocrimpol» project: methodology of analysis. Proceedings from the Conference: Kryminalne pravo v umovakh hlobalizatsii: materialy Mizhnar. nauk.-prakt. konf. - Criminal Law in the context of globalization: materials Intern. Research Practice Conf., (Pp. 63-65). Odesa: NU OLA. P. 65 [in English]; Communication from the Commission to the European Parliament, the Council, the European Economic and Social Committee and the Committee of the Regions. Delivering an area of freedom, security and justice for Europe's citizens. Action Plan implementing the Stockholm Programme - COM(2010)171 final, 20 April 2010. (2010, April 20). [in English].
} 
cause the greatest damage not only at the national but also at the international level.

Recommendations formulated in the Strategic Guidelines for Legislative and Operational Planning in the Area of Freedom, Security and Justice, adopted by the European Council of 27 June 2014, and the Strategic Guidelines for Justice and Home Affairs cover aspects such as border control, migration and asylum policies, police and judicial cooperation.

Areas such as migration and asylum, the fight against terrorism and the protection of personal data, which have a global dimension, must be addressed both within the EU and in relations with third countries.

On the issue of illegal migration, strategic recommendations call for action aimed at overcoming the root causes of this phenomenon and overcoming migration flows. In both of these aspects, cooperation with the countries of origin and transit of migrants plays a fundamental role. This cooperation on migration is defined in the global approach to migration and mobility, within the EU for dialogue and cooperation with non-EU countries of origin, transit and destination.

The main tasks of the European Council on illegal migration were: to strengthen and expand regional protection programs, to compel smuggling and human trafficking, to implement an effective common return policy.

Addressing human trafficking is part of the United Nations Sustainable Development Program. According to Art. 3 of the Protocol to Prevent, Suppress and Punish Trafficking in Persons, Especially Women and Children, supplementing the UN Convention against Transnational Organized Crime, adopted by General Assembly resolution 55/25 of 15 November 2000: "Trafficking in human beings» means committed for the purpose of exploitation of the recruitment, transportation, transfer, concealment or receipt of persons by threat of force or its use or other forms of coercion, abduction, fraud, abuse of power or vulnerability, or by bribery, in the form of payments or benefits, to obtain the consent of the person controlling the other. Exploitation shall include, at a minimum, the exploitation of the prostitution of others or other forms of sexual exploitation, forced labor or services, slavery or customs similar to slavery, servitude or removal of organs. 
According to the Global Trafficking in Persons Report $2018^{4}$ trafficking in human beings for sexual exploitation remains the most prominent form.

Countries around the world are finding and reporting more victims and condemning more traffickers. Although the number of reporting countries has not increased significantly, the overall number of casualties in each country is increasing. In previous years, for which UNODC collected these data, the trend of the average number of identified and reported victims per country has fluctuated previously, but has increased steadily over the last few years.

As stated in the Preamble to the Protocol, States Parties, stating that a comprehensive international approach in countries of origin, transit and destination, including preventive measures, is needed to take effective measures to prevent and combat trafficking in human beings, especially women and children. Such trafficking, the punishment of persons engaged in it, and the protection of victims of such trafficking, including through the protection of their internationally recognized human rights.

In Chapter III of the Council of Europe Convention on Action against Trafficking in Human Beings from May 16, 2005 there are certain «stepby-step» interrelated measures, in particular: prevention of trafficking in human beings (Article 5), measures to discourage demand (Article 6), border measures (Article 7), security and control of documents (Article 8), legality and validity of documents (Article 9). In particular, Art. 7 of the Convention «Border measure» indicated that would without prejudice to international commitments on free movement of persons Parties shall strengthen, to the extent possible, such border controls as may be necessary to prevent and detect trafficking.

On the plus side, these measures are not separate from each other but represent a specific system.

In accordance with the decision «On Prevention of Trafficking in Human Beings» No. 6/17, December 8, 2017, it is necessary to promote

${ }^{4}$ The institutions, which are engaged in trafficking human beings, should have the opportunity to define the various and often complex contexts and realities, in which there is sexual exploitation, with the aim of responding to physical, psychological, social and economic needs of the victims. Trafficking in children - especially girls - remains a key issue. The implementation of measures to combat child trafficking for children may be more effective if they are included in quality education programs for all, especially in the context of increased risk of trafficking in human beings, such as refugee camps. / (2018). Hlobalnyi zvit pro torhivliu liudmy. [Global Trafficking in Persons Report]. Retrieved from https://reliefweb.int/report/ world/global-report-trafficking-persons-2018. [in Ukrainian]. 
the implementation of multi-agency, cross-sectoral and multinational programs aimed at preventing trafficking in human beings in all its forms, with particular emphasis on the factors that affect people to human trafficking; take appropriate measures to effectively combat trafficking in human beings through the development of harmonized procedures and training courses, in particular to identify and protect victims of trafficking in human beings, including relevant authorities, civil society organizations, medical and social workers, and others who may have first contact with victims; implement a gender-sensitive approach that fully respects human rights and fundamental freedoms in all preventive and supportive measures ${ }^{5}$.

This mechanism seems rational, because if it does not work a preventative measure, you can go to corrective or alternative. In addition, it combines both purely criminal and criminal proceedings, as well as civil.

Domestic and foreign scientists (V.O. Tuliakov, M.I. Khavroniuk, I.M. Gorbacheva, O.V. Kozachenko) also turn their attention to the multi-track system of criminal-law influence, but in practice it is not yet embodied in full.

With the adoption of the Criminal Code in 2001, it became possible to prosecute trafficking in human beings. According to Part 1 of Art. 149 of the Criminal Code (as amended by the Law of Ukraine «On Amendments to Article 149 of the Criminal Code of Ukraine on Compliance with International Standards» No. 2539-VIII of September 6,2018 ) trafficking in human beings, as well as the recruitment, transfer, transfer or getting a person committed for the purpose of exploitation, using coercion, abduction, deception, blackmail, material or other dependence of the victim, his vulnerable condition or bribery of a third person who controls the victim to obtain consent for his exploitation.

However, despite the possibility of bringing persons involved in trafficking in persons to criminal liability, as well as the corresponding changes aimed at bringing in compliance with Art. 149 of the Criminal Code with international standards, counteraction and prevention of such acts, ensuring protection of victims of human trafficking remains relevant.

\footnotetext{
${ }^{5}$ Strengthening efforts to prevent trafficking in human beings decision No. 6/17, 8 December 2017 (2017, December 8). Retrieved from https://www.osce.org/chairmanship/ 362096?download=true. [in English].
} 
In international norms, the issue of victims of trafficking in human beings is given considerable attention. According to Art. 6 of the Protocol on the Prevention and Suppression of, and Punishment for, Trafficking in Persons, Especially Women and Children, supplementing the UN Convention against Transnational Organized Crime of 15 November 2000 provides for measures to assist and protect victims of trafficking in human beings.

In summary, the following can be summarized as follows: protection of privacy, including, inter alia, by ensuring the confidential nature of trade-related proceedings; providing information on appropriate judicial and administrative proceedings; assistance that does not prejudice the rights of the defense and allows them to express and consider their thoughts and fears at the appropriate stages of criminal proceedings against the perpetrators; physical, psychological and social rehabilitation of victims of trafficking in human beings (in particular, proper roofing, advisory assistance and information, especially regarding their legal rights, language, clear victims of human trafficking, medical, psychological and material assistance, employment, education and vocational training opportunities).

In addition, the age, gender and special needs of victims of trafficking in human beings, including the special needs of children, including proper roofing, education and care, should be taken into account, as well as a real mechanism to compensate victims of trafficking for harm.

According to Art. 9 of the Protocol, with a view to preventing trafficking in human beings and protecting victims of trafficking in human beings, especially women and children, from the state party's revitalization, elaborate and adopt comprehensive policies, programs and other measures; seek to take measures such as research, information campaigns, including in the media, as well as socio-economic initiatives aimed at preventing and combating trafficking in human beings; take or improve, including through bilateral or multilateral co-operation, measures aimed at mitigating the effects of trafficking-related factors such as poverty, low development and lack of equal opportunities; take or improve legislative or other measures, such as in the fields of education, culture or the social field, including through bilateral and multilateral cooperation aimed at counteracting the demand for exploitation of people, especially women and children, in all its forms, leads to human trafficking.

Also note the provisions of Directive 2011/36 / EC of 5 April 2011 of the European Parliament and of the Council on the prevention and 
suppression of trafficking in human beings and the protection of its victims; Directive 2017/541 of 15 March 2017 of the European Parliament and of the Council on the Suppression of Terrorism; Council Framework Decision 2008/913 / JHA of 28 November 2008 on combating certain forms and manifestations of racism and xenophobia and others.

It should be noted that organized crime and terrorism are often linked to human trafficking.

Strategic guidelines for justice and home affairs include: mobilizing all instruments of judicial and police cooperation, strengthening the role of Europol and Euro just in the fight against organized crime and terrorism ${ }^{6}$. It should also support: reviewing the internal security strategy, developing a comprehensive approach to cyber security and cybercrime, preventing radicalization and extremism.

Terrorism is increasingly functioning as a business that is dependent on criminal organizations and fueled by corruption. Terrorists are diversifying their range of illegal products. Illicit trafficking in weapons, persons, drugs, smuggling and falsification of cigarettes and alcohol, falsification of drugs, smuggling of antiquities and natural resources (gold, precious metals, stones, minerals, wildlife products) are used to profit and finance acts of terror. coal and oil). Terrorists as well as organized criminals need professional services: expert facilitators allow terrorists to participate in cost-benefit analysis, control supplies, seek strategic alliances ${ }^{7}$.

Anti-corruption. The risk of corruption is also due to the impact on other crimes of the European integration area (terrorism, organized crime, trafficking in human beings, illegal migration, etc.).

Corruption is the basis for terrorist offenses, as it undermines governance, the economy, health, the social sphere, order and sustainable development in all regions of the world. It deligimizes public services by facilitating crime. This is precisely what experts say about the need for a unified international approach to combating corruption.

${ }^{6}$ Strengthening efforts to prevent trafficking in human beings decision No. 6/17, 8 December 2017 (2017, December 8). Retrieved from https://www.osce.org/chairmanship/ 362096?download=true. [in English]..

Nikolenko, R.O. (2019). Kryminalno-pravova protydiia zlovzhyvanniu povnovazhenniamy osobamy, yaki nadaiut publichni posluhy [Criminal legal counteraction to abuse of power by persons providing public services]. Candidate's thesis. Odesa: NU OLA. P. 23-24. [in Ukrainian]. 
Trafficking in human beings, trafficking in human beings, arms and drugs trafficking, exploitation of prostitution, illegal migration, trafficking in cultural heritage, encroachment on environmental security are supranational and impossible without arranging and using a transnational network of persons specializing in the provision of specific or special services. In the exercise of power over and above the public interest. According to experts from the UN Commission on Crime Prevention and Drug Trafficking, terrorists, as well as organized criminals, are involved in corrupt operations with government officials for their own survival, as they depend on arms smuggling and the shadow market for conspiracy officials.

Therefore, countering corruption offenses should be systemic. But a strategy whereby government officials are substantially restricted in their right to be justly punished leads to a shadowing of relations and an increase in non-institutional services and criminal practices. For example, it is advisable to introduce a number of restrictions on persons who have committed a corruption crime. However, it is not in a way that contradicts the CC of Ukraine ${ }^{8}$. However, the adoption of a number of anti-corruption laws does not contribute to such systematicly.

\section{European integration and challenges of the information society}

European integration trends are also largely dependent on the opportunities and challenges of the information society. The rapid development of technological processes in an information society environment has also led to criminal attacks on the security of this field. Issues related to the Internet of Things, the mass spread of spam, issues of the rights, responsibilities and responsibilities of robots, artificial intelligence, and the spread of human rights abuses using information technology, including the commission of crimes, were updated.

The EU is responding quickly enough to changing public relations. On 13 February 2019, the Committee of Ministers of the Council of Europe adopted a Declaration on the Manipulative Capabilities of Algorithmic Processes, which states that Member States should ensure the rights and freedoms enshrined in the Convention for the Protection of Human Rights and Fundamental Freedoms (ETS No. 5) under their

\footnotetext{
8 Nikolenko, R.O. (2019). Kryminalno-pravova protydiia zlovzhyvanniu povnovazhenniamy osobamy, yaki nadaiut publichni posluhy [Criminal legal counteraction to abuse of power by persons providing public services]. Candidate's thesis. Odesa: NU OLA. P. 28. [in Ukrainian].
} 
jurisdiction, as well as offline and online, in the face of unprecedented political, economic and cultural globalization ${ }^{9}$.

It should also be noted that the provisions set out in the Declaration are justified by the fact that the Council of the Member States of Europe has undertaken to build a society based on the values of democracy, human rights and the rule of law. This commitment remains and must be fulfilled through a long process of transformation of society, fueled by technological advances.

It should be borne in mind that the use of Internet of Things technologies creates both positive points and significant risks, in particular in terms of the development of the humanistic paradigm.

«Internet of Things» means complexes and systems consisting of sensors, microprocessors, actuators, local and / or distributed computing resources and software, artificial intelligence applications, cloud computing, data transmission between which is carried out via the Internet, and intended for rendering services and carrying out works in the interests of subjects (legal or natural persons). As notes O.A. Baranov, «society is not in a position to make informed decisions, because the modern process of their adoption is characterized by the fact that it is necessary to take into account significant amounts of information (data); a large number of actors and objects involved in the decision-making process; in most cases, it must be resolved in real or for a limited time. The output is seen in the application of Internet of Things technologies because they allow you to make and execute decisions in real time based on the use of mathematical algorithms, including algorithms of artificial intelligence, the collection and processing of vast amounts of data, the identification of all objects that take participation in processes»» ${ }^{10}$.

In today's context, it is really impossible for such a person to analyze such a large amount of information, or not to be able to do so in such a short period of time. Using Big Data (making decisions based on too

\footnotetext{
${ }^{9}$ Declaration by the Committee of Ministers on the manipulative capabilities of algorithmic processes (Adopted by the Committee of Ministers on 13 February 2019 at the 1337th meeting of the Ministers' Deputies). (2019, February 13). Retrieved from https://search.coe.int/cm/ pages/result_details.aspx?objectid=090000168092dd4b. [in English].

${ }^{10}$ Baranov, O.A. (2016). «Internet rechei» yak pravovyi termin [«Internet of Things» as a legal term]. Yurydychna Ukraina - Legal Ukraine, 5-6, 96-103. [in Ukrainian].
} 
much information $)^{11}$ and Internet of Things technologies could help a person.

For example, the processing of property declarations in the short term and taking into account many factors for analysis while correlating this information with other sources (in particular, through the «you control» capabilities) would contribute to the timely detection of corruption, corruption risks and accordingly to counteraction and prevention corruption. That is, the Internet of Things would help the state fulfill its function of ensuring its own security and that of the society as a whole.

The state is now ready to cede to the fundamental humanistic rights, freedom and security of its citizens, morality for the sake of security from certain crimes, in particularly grave crimes with a cross-border dimension. These include, for example, terrorism, trafficking in human beings, sexual exploitation of women and children, drug and weapons trafficking, money laundering and counterfeiting, corruption, cybercrime and organized crime.

To prevent crime, the state at the level of the law allows derogating from absolute prohibitions of encroachment on property, health and even human life, as well as privacy. The state justifies such steps by the absence of other means to counteract crime. At the same time, it should be remembered that such retreats are allowed in order to protect human rights and freedoms, and not vice versa.

Although the latest TARICCO II, ECJ 2017, TSEZAR AND OTHERS v. UKRAINE, ECHR 2018, demonstrate the collective priority over the individual (European and national values) and the authority to punish their citizens.

However, due to the processing and availability of big data, including «big private data», there are other issues related to the security of a particular person and their private information.

For example, in modern China, there is a system of disclosure of private information in public access, according to which the «rating of the person» is formed and taken into account when hiring, etc. In Ukraine, as well (though not officially) for individual positions, the person is checked, including through social networks and media (for

${ }^{11}$ Karchevsky, M.V. (2016). Mozhlyvosti Big Data ta kryminalno-pravova komunikatsiia [Big Data Opportunities and Criminal Communications]. Proceedings from the Conference: Polityka v sferi borotby zi zlochynnistiu: Mizhnarodna naukovo-praktychna konferentsiia Crime Policy: International Scientific and Practical Conference (Pp. 52-58). Ivano-Frankivsk. [in Ukrainian]. 
example, to work in the Anti-Corruption Court). Regular users of the Internet are already actively using programs to identify a person's location using a mobile phone, applications that allow you to view contacts in another person's mobile phone, etc. All this breaks privacy. But how much are we ready to give in to our freedom and privacy in the future for the sake of state security.

When it comes to the use of Internet of Things technologies, they carry as positive aspects related to ensuring the security of the state, but carry the risks of not being able to control their own lives by citizens of the state. It is unknown who and for what purpose personal data will be used, how and under what circumstances it will be used against people ${ }^{12}$.

Proponents of the use of «big data» including to counter the crime refer to the fact that an honest human has nothing to hide. But the question is not so much whether the person has something to hide, but whether she has the choice to share her personal information with the public, whether she can control the use of her data in the future (who watched, for what purpose, etc.), as well as who will be responsible for the misuse of such information, including the commission of crimes against that person and the manipulation of personal data about which he or she has shared access.

The technological capabilities of the Internet make it easier to commit crimes. In particular, corruption practices make it easier to pay for corruption services through electronic money (Bit coin, Satoshi, Ethereum, etc. $)^{13}$. Social networks allow you to register not under your own name, etc. In addition, Internet capabilities have simplified the spread of pornography, including child pornography, the use of prostitution services, prostitution has emerged online (the so-called webcam model), facilitated the sale and sale of organs, trafficking in

\footnotetext{
${ }^{12}$ For example, criminal proceedings are strictly regulated by law, including procedures for the taking of evidence. If a person collects evidence in contravention of the procedure prescribed by law, they cannot be admitted with proper and admissible evidence and accordingly used in criminal proceedings. Although now, the correspondence on Facebook and other social networks, photos, account information and more are provided as evidence. In addition, you should pay attention to video creation technologies, photoshop and more.

${ }^{13}$ To use electronic money for perpetrators of crime is convenient and advantageous for many reasons. Firstly, they are not currently recognized as the national currency of Ukraine, and accordingly, they are not taxable; the procedure for their production and legitimating has not been approved, therefore it is impossible to prosecute for the illicit manufacture of such money. Second, it is not possible to personalize the payer for third parties. However, the movement of transactions is seen very well.
} 
human beings and the like. That is, in order to commit cross-border crimes, you do not even need to cross the border now.

However, it should also be noted that information technology is also of great benefit, in particular from a humanistic paradigm perspective, information technology facilitates the retrieval and processing of information that contributes to crime prevention.

Therefore, greater attention should be paid to regulating these issues. In particular, refer to European Criminal Law sources (for example, the 2016/679 Shared Data Protection Rules, applicable from 25 May 2018, which include specific rules for the control of personal data of individuals to prevent, investigate, detect or prosecute criminal offenses, or enforcement of criminal penalties), Directive 2013/40 / EC of 12 August 2013 of the European Parliament and of the Council on the fight against information systems.

Strengthening interpersonal contacts. However, as one legal regulation has repeatedly stated, it is not possible to effectively influence the commission of crimes, especially of a supranational nature. This requires other mechanisms. Such mechanisms can be negotiation, dialogue, mediation practices that contribute to the peaceful settlement of disputes.

Goal 16 of the United Nations on Sustainable Development from 2016 to 2030 is «Promoting a Peaceful and Open Society for Sustainable Development, Ensuring Access to Justice for All», which fully complies with the humanistic planning concept that takes everyone's mind into account.

According to Art. 33-1 Chapter VI of the UN Charter (Peaceful Settlement of Disputes) ${ }^{14}$ the parties involved in any dispute which may continue to threaten the maintenance of international peace and security should, first of all, seek to resolve the dispute through negotiation, mediation, conciliation, arbitration, litigation, referral to regional bodies or agreements or other by peaceful means of their choice. The Security Council, when it considers it necessary, shall require the parties to resolve their dispute by such means. Without prejudice to the provisions of Articles 33-37, the Security Council shall be empowered if all parties involved in any dispute so request to make recommendations to the parties with a view to the amicable settlement of this dispute (Article 38).

${ }^{14}$ The Charter of the United Nations and the Charter of the International Court of Justice. (N.d). Retrieved from https://treaties.un.org/doc/publication/ctc/uncharter.pdf. [in English]. 
Dialogue practices can also contribute to the compensation and restitution of crime victims.

In addition, as outlined in the Preamble to Recommendation No. R (99) 19 of the Committee of Ministers of the Council of Europe to Member States on criminal mediation of 15 September 1999, mediation is able to increase awareness of the important role of the individual and community in crime prevention and development related conflicts, thereby contributing to the more constructive and less repressive consequences of criminal justice.

The case law of the European Court of Human Rights imposes human rights standards. Effective protection of human rights and freedoms is an integral part of a legal, democratic state. Human rights are understood as universal, inalienable and equal for each person the basic capabilities necessary for their existence and development, which are defined and guaranteed by the state in the scope of international standards. According to the Law on the Enforcement of Judgments and the Practice of the European Court of Human Rights, the courts of Ukraine use the ECtHR and it is a source of law.

In the changing modern world, it is necessary to make a humanistic paradigm an effective model of transformation of legislation, criminal policy, law enforcement practices taking into account European integration tendencies.

It is necessary to establish the directions of Criminal Law policy and specific models of Criminal Law providing for agreements on association of EU member states, as well as their doctrinal basis.

The new structure of Criminal Law and its theoretical basis must be analyzed and formulated, focusing on European Criminal Law policy (EU rules affecting Ukrainian law, judicial and preventive practice). In such a situation, the strategic guidelines, tasks, directions and goals of the criminal impact on crime against the basics of the economy, migration order, environmental security, cyber security, as well as the criminal justice provision of anticorruption security of economic activity and the means to achieve them need to be revised; sources and procedural elements and instruments of European Criminal Law ${ }^{15}$.

15 Tuliakov, V.O. (2018). «Eurocrimpol» project: methodology of analysis. Proceedings from the Conference: Kryminalne pravo v umovakh hlobalizatsii: materialy Mizhnar. nauk.prakt. konf. - Criminal Law in the context of globalization: materials Intern. Research Practice Conf., (Pp. 63-65). Odesa: NU OLA [in English]. P. 65. 


\section{CONCLUSION}

Criminal Law should help to meet the human natural needs, in particular in security and freedom. When a person feels safe, he or she is open to development, to interaction with others (including the state). In the context of European integration, it is important for state to form a legitimate Criminal Law, that is, one that is perceived and accepted by the citizens of a state that is geared to the needs of human beings. It is desirable that the state take care of the benefits of choosing right-wing behavior (so that such a choice does not contradict the natural needs of the individual, including privacy).

The Criminal Code of the future should be guided by current conditions and opportunities (in particular, the capabilities of the Internet of Things), as well as the actual needs of modern people. It seems that we should start with agreements between the state and civil society about their list, the objectives of the criminal legislation and the limits of its intervention, the list of principles of lawmaking and enforcement. Then, formulate new legislation in accordance with the needs of the individual, society and state, and bring into force the current legislation.

In the context of European integration, in addition to the classic instruments of counteraction to crime (reaction to crime) (for crime punishment), it is advisable to develop restorative, dialogical practices, practices of nonviolent communication.

\section{SUMMARY}

One of the main tasks of Criminal Law is to ensure the human security and freedom. Contradictions between the attainment of individual liberty and the security of the state, in particular, can be traced to issues related to migration processes, transborder crimes, etc.

The implementation of the Association Agreement between Ukraine, on the one part, and the European Union, the European Atomic Energy Community and their member states have resulted in a set of significant changes in Ukraine. European integration trends are implemented both in general terms and in separate institutes of Criminal Law (in particular, the specifics of criminal liability).

The Association Agreement contains several important areas of humanistic content that are directly related to the criminal law policy and which Ukraine seeks to implement and to become closer to the EU legislation. Among them, in particular, - counteracting illegal migration and trafficking in human beings, organized crime, terrorism, environmental protection, strengthening of people-to-people contacts. 
It is important that the acts of the European Union and the Council of Europe not only declare certain principles but also provide for specific mechanisms for their implementation, as well as demonstrate a response to their violation.

The EU shows a quick reaction to change social relations. For example, modernity is characterized by the rapid development of information technology, the Internet of Things, and, accordingly, the spread of human rights violations, using information technologies, including the commit of crimes.

Strategic guidelines, tasks, directions and objectives of criminal legal influence on the crime against the bases of the economy, the order of migration, environmental security, cyber security, as well as criminallaw support of anticorruption security of economic activity and means of their achievement are required; sources, as well as procedural elements and instruments of European criminal law. In particular, it is necessary to harmonize Criminal Law with the practice of the ECtHR.

Criminal Law should contribute to the protection of human natural needs, in particular in the area of security and freedom.

\section{REFERENCES}

1. Trykhlib, K.O. (2014). Harmonizatsiia zakonodavstva Ukrainy i zakonodavstva YeS: nablyzhennia zahalnopravovoi terminolohii [Harmonization of Ukrainian and EU legislation: approximation of common law terminology]. Extended abstract of candidate's thesis. Kharkiv: NLU. Y. the Wise. [in Ukrainian].

2. Timofeyeva, L.Yu. (2019). Euro-integration and Criminal Law policy. Proceedings of the Int. sci. conf.: ECHR's Jurisprudence in Digital Era. (Pp. 93-93). Odesa: Publishing house "Helvetica. [in English].

3. Timofeyeva, L.Yu. (2018). Humanistychna paradyhma kryminal'noho prava Ukrayiny. [Humanistic paradigm of Criminal Law of Ukraine]. Extended abstract of candidate's thesis. Odesa: NU OLA. [in Ukrainian].

4. Tuliakov, V.O. (2018). «Eurocrimpol» project: methodology of analysis. Proceedings from the Conference: Kryminalne pravo $v$ umovakh hlobalizatsii: materialy Mizhnar. nauk.-prakt. konf. - Criminal Law in the context of globalization: materials Intern. Research Practice Conf., (Pp. 63-65). Odesa: NU OLA [in English].

5. Action Plan implementing the Stockholm Programme $\operatorname{COM(2010)171~final,~} 20$ April 2010. (2010, April 20). [in English]. 
6. (2018). Hlobalnyi zvit pro torhivliu liudmy. [Global Trafficking in Persons Report]. Retrieved from https://reliefweb.int/report/world/ global-report-trafficking-persons-2018. [in Ukrainian].

7. Strengthening efforts to prevent trafficking in human beings decision No. 6/17, 8 December 2017 (2017, December 8). Retrieved from https://www.osce.org/chairmanship/362096?download=true. [in English].

8. Nikolenko, R.O. (2019). Kryminalno-pravova protydiia zlovzhyvanniu povnovazhenniamy osobamy, yaki nadaiut publichni posluhy [Criminal legal counteraction to abuse of power by persons providing public services]. Candidate's thesis. Odesa: NU OLA. [in Ukrainian].

9. Declaration by the Committee of Ministers on the manipulative capabilities of algorithmic processes (Adopted by the Committee of Ministers on 13 February 2019 at the 1337th meeting of the Ministers' Deputies). (2019, February 13). Retrieved from https://search.coe.int/ $\mathrm{cm} /$ pages/result_details.aspx?objectid=090000168092dd4b. [in English].

10.Baranov, O.A. (2016). «Internet rechei» yak pravovyi termin [«Internet of Things» as a legal term]. Yurydychna Ukraina - Legal Ukraine, 5-6, 96-103. [in Ukrainian].

11. Karchevsky, M.V. (2016). Mozhlyvosti Big Data ta kryminalnopravova komunikatsiia [Big Data Opportunities and Criminal Communications]. Proceedings from the Conference: Polityka $v$ sferi borotby zi zlochynnistiu: Mizhnarodna naukovo-praktychna konferentsiia - Crime Policy: International Scientific and Practical Conference (Pp. 52-58). Ivano-Frankivsk. [in Ukrainian].

12. The Charter of the United Nations and the Charter of the International Court of Justice. (N.d). Retrieved from https://treaties.un.org/doc/publication/ctc/uncharter.pdf. [in English].

\section{Information about the author: Liliya Timofeyeva,} $\mathrm{Ph} . \mathrm{D}$, assistant professor of Criminal Law Department of the National University «Odesa Law Academy»,

23 Fontanska dor. str., Odesa, Ukraine, 65-000 ORCID ID: https://orcid.org/0000-0002-6968-6587 